\title{
The CECL's First Fifty Years
}

\begin{abstract}
The first Conference of Eastern College Librarians was held in 1912; in 1964 the fiftieth such conclave took place. Throughout its history the CECL has been noted for its informality, its independence, and its prophetic concern for matters that later command the attention of the entire profession. Led in its early years by strong individual librarians-such as Columbia's C. C. Williamson-the CECL has latterly taken its direction from a steering committee.
\end{abstract}

C

AERTAIN SINGULARITIES of this fiftyyear-old Conference of Eastern College Librarians should be noted. These include: its informality; its long fidelity to Columbia; a total inconsistency with respect to its name (anyone may come, even library patrons); its coincidence with America's great feast day; its continuing location in one of America's better holiday towns; its wholly independent status; and its total want of membership, minutes, constitution, by-laws, business proceedings, money mulcts in the form of dues, and other trappings of the more formalized library conferences.

But the singularities do not end there. For example, even the hastiest examination of its program contents will show how little given this Conference has been to self-analysis, to brooding over its identity, to introspection or even to retrospection in any form. In fact, it has carried these selfless qualities to the point where one might legitimately ask whether such a paper as this one belongs on the Conference program at all, and

Mr. Turner is Lecturer in the School of Library Service at Columbia University. This paper is printed as read to the fiftieth Conference of Eastern College Librarians in New York on November 28, 1964. especially on this fiftieth anniversary occasion when silence itself might well be golden.

Yet having been made the Conference's antiquary, I am not easily silenced now. After spending several months off and on in poking around in its past, fingering its relics, and inhaling its dust, I have become attached to this Eastern Conference, as one fifty-year-old to another. And hence I run the risk of saying not too little on this occasion but rather too much.

As antiquary then I am drawn firstalmost in Old Testament style-to the people who have run the Conference through the years. "In the Beginning" there was W. Dawson Johnston of Columbia, who ran it for two years before going on to his reward. And that was to Paris as director of the American Library there. Next came William Coolidge Lane of Harvard, and William C. Hicks of Columbia, who ran it in tandem for three years; then Hicks alone for ten years more before going on to his reward, and that was Yale (no Bois de Boulogne, of course, but a good place even so). Next came Harriet B. Prescott, Columbia's chief cataloger, who ran it as an interim matter for one year. Then, with two years of assistance from Miles 
O. Price while sidelined by illness, C. C. Williamson ran it for fourteen years, and Carl M. White for several more. Thereafter the responsibility passed into the hands of its steering committees where it has remained ever since. By every show of the record, I might add, these committees have done their work effectively and with good grace. But then I would be neglecting my own responsibilities as antiquary if I failed to point out that here and there the record has also turned up a chairman who sounded a little harassed and overburdened, and a little like the man Lincoln once described, who after being tarred and feathered, and about to be ridden out of town on a rail said, "if it weren't for the honor of the thing, I'd just as soon walk."

Of all the people, however, who have run the Conference, Dr. Williamson is the one I would most like to linger with now for a bit. He is an extraordinary man, if you don't know him-a spare and erect eighty-eight-year-old, still very much alive, living in Greenwich, Connecticut, and not only running the Greenwich Garden Club now but the club's library as well. Dr. Williamson came to Columbia in 1926, you may remember. He came by way of Bryn Mawr where he taught economics, the New York public library where he had been chief of the economics and business division, the Rockefeller Foundation for which he did an Americanization study, and the Carnegie Corporation which sponsored his report on American library education which he alone refers to today as the "Carnegie Report."

His fourteen-year stewardship of the Conference was remarkable in many respects. For one, he was simultaneously managing two other sizeable enterprises: the Columbia University library system and its school of library service. But more remarkable, I think, is the way in which he ran the Conference as if it were a kind of third Indian club he kept twirling in the air. And he did so with a sure hand, with flare, and with much dexterity, which make the Conference seem all the more worth celebrating today. As Dr. Williamson cheerfully acknowledged to me not long ago, he had one serious administrative flaw. $\mathrm{He}$ found it almost painfully hard to delegate detail. But not for want of faith in his subordinates. Rather, I suspect, because he was so fond of detail himself.

In any case, at his desk, first in Low library and then in Butler, he centralized the entire responsibility for the Conference. From there he ran the whole show. $\mathrm{He}$ handled the delicate business of speaker and topic procurement, and incidentally, he had quite a knack for that. Almost ingenuously, he would write people asking their suggestions for topics. Then once he had them, he would ask the same people who suggested them to speak on them. And often enough they would.

Also, Dr. Williamson arranged for the annual meeting place as it moved successively from Milbank chapel to the Men's Faculty Club and the Women's, to Casa Italiana, and finally to Harkness. He screened the mailing lists. He saw to the mailings. He handled all the correspondence, both outgoing and incoming, relating to the Conference. By far the most of the incoming mail was laudatory, but occasionally it could be cranky, as when a college librarian in New Jersey complained she had heard so many talks on the Library of Congress that she could now make one on it herself.

He also prepared, edited, and all but saw the annual program through the press. And that could be a hazardous job, like the year he left off Isadore Mudge's middle initial, or the time when right up until the final galley proof, Keyes D. Metcalf was unaccountably down to discuss "bar, college, and research libraries" instead of the more sobering "university, college and research libraries."

Dr. Williamson also handled the Con- 
ference's finances, such as they were. And that could be another precarious task considering that the Conference seldom had more than five dollars to its name (it always passed the hat in those days) and that more than once he had to throw not only his own considerable prestige but all of Columbia's behind him as well, in prevailing upon one of the city's larger banking systems to carry this blue chip account.

But even all these were not the end of his tasks. Besides carrying the full load of this Saturday's proceedings on his shoulders, he also took it upon himself every year to run a kind of Conference Within a Conference, or, more accurately, a Conference Before a Conference. And this was the annual Friday Night Dinner and Smoker afterwarda kind of stag at eve at which presumably no one drank more than his fill.

I cannot resist going on about these Friday night dinners for a bit. They were highly honorific affairs, freighted with status, and hedged all about with restrictions. They were restricted first to men, and then more specifically, to those who after years on the slippery ladder upwards, now perched securely on the top rungs, great gray eagles of the American library scene. They were men like the Goodriches of the College of the City of New York and Dartmouth; Mark Llewellyn Raney of Johns Hopkins; Otto Kinkeldey of Cornell; Andrew Keogh of Yale; William Warner Bishop of Michigan; Fremont Rider of Wesleyan; Milton Lord of the Boston public library; Henry Lydenberg and Paul North Rice of the New York public library, and Keyes Metcalf of Harvard. In short, The Establishment.

According to a Friday Night "regular" of the period, the dinners were both serious and informal. They began with general conversation. Then around coffee and dessert time, an unobtrusive agenda would begin to function. Paul North Rice, Keyes Metcalf, or Dr. Williamson himself would toss out a library subject for discussion. Often it bore on some action of the ALA Executive Council. Just as often it was a rehash of what the Association of Research Libraries, another elite, was talking about. Moreover, there seems to have been a perennial gripe around the table about the $\mathrm{Li}$ brary of Congress' cooperative cataloging venture and about the way LC kept bouncing cards back for correction until the catalogers were scared to death even to send copy in. The Friday Nighters talked about public documents, too, and the need for better numbering and indexing systems. And since, as my informant told me, these dinners were held in the period when microfilm was in its ascendancy, much as automation is today, they also discussed that. I was further told that it was as important for a man to be able to discourse knowingly about "salts of bromide" and the relative reduction ratios of 8,16 , and $35 \mathrm{~mm}$ microfilm then as it is to do so about "parameters" and "printouts" and "simulation studies" today.

Now while these dinners were tightly restricted affairs, occasionally the group would make room at the table for a young man on the way up, a Danton or a Fleming, for example. But never under any circumstances would they make room for a woman. How inflexibly this rule operated is shown in a letter Dr. Williamson wrote-with tongue in cheek, I am sure-to a colleague upstate who was unable to attend one year and was brash enough to suggest that a certain female on his staff attend in his place. Said Dr. Williamson:

I am sorry it will not be practicable to ask Miss W. to represent you because this little dinner is an intimate stag affair . . . always has been, and I am sure I would incur the wrath of all the men who attend if I were to invite a mere woman.

Now these were fighting words and in 
a later day and age perhaps enough so to start a battle of the sexes on the spot. But as it was, the women of the Conference retaliated in the only way they felt they could at that time. They started a Friday night dinner of their own in the Women's Faculty Club next door. Cigars and tiparillos not then being in vogue among women, I do not believe there was a smoker afterwards. But certainly these dinners had a prestige of their own with such luminaries around the table as Flora Belle Ludington, Miss Mudge, Minnie E. Sears, Lavina Stewart, Julia Pettee, and of course, Mrs. C. C. Williamson.

But all of this is simply by way of insisting that Dr. Williamson was rarely gifted, especially where the Conference was concerned, and I think it is fair to say, with due respect to all who have followed him since, that much that is best about the Conference today still bears his imprint. When I saw him last autumn, he wore the red ribbon of the Legion of Honor in his lapel. He told me, by the way, that any number of people had offered to snip it off for him, thinking it was the string of a dry cleaner's tag inadvertently left there. In any case, while the ribbon was worn for his work in helping to promote funds for the printed catalog of the Bibliothèque $\mathrm{Na}$ tionale we now have, it might have represented all his many distinctive contributions to the Conference just as well.

And that leads me to a second point about the Conference. Even Williamsons get weary. And after so many years of running the Conference all but single handedly, he became so himself. So much so, in fact, that the status of the Conference itself as we know it today became gravely imperiled. Dr. Williamson wanted to be relieved of the responsibility, and asked that another mechanism for carrying it on be established.

Earlier I mentioned that the Conference had never gone in much for self- examination, at least not publicly. But there was one time it did and that came in 1939, in the impasse at hand, when with Dr. Williamson's full endorsement and with the consent of others, Willard P. Lewis, librarian of Pennsylvania State College and soon to become secretary of the Association of College and Reference Librarians, spoke on "The Future Status and Conduct of the Conference of Eastern College Librarians." In his talk, Mr. Lewis offered three alternative proposals for the Conference's future: (1) that it remain wholly independent (and I do not think Mr. Lewis' heart really was in that); (2) that it be absorbed within the Association of College and Reference Librarians; and (3) as a kind of compromise between the first two proposals, that it merely affiliate with ACRL.

It was number three which $\mathrm{Mr}$. Lewis seemed to favor most himself. It would, he said, mean neither loss of autonomy nor of Columbia as the meeting place. Moreover, the college library subsection of the association would take over all the chorework of running the Conference, even to underwriting its cost and thus giving it a sense of moneyed amplitude which until then it had never enjoyed. And finally as an added dividend, Mr. Lewis offered to have the annual proceedings of the Conference published in the new ACRL Quarterly. As it might even today, Mr. Lewis' proposal had a certain glitter and seductive charm to it. There is something to be said, after all, for the life of a kept conference. And so the proposal did draw some serious consideration. But in the end, the Conference showed not only its spirit of independence but its moral fibre as well. It voted to continue going it alone, solitary, unkept, and untarnished. And a loner it has been ever since.

But to the one factor, weariness, which had imperiled the Conference, another should be added, too. And that was Columbia's continuing sensitivity about 
seeming to monopolize the Conference, to hug it too close, to own it. Dr. Williamson had said one year himself that he was coming to feel like an hereditary monarch, a veritable king of the Conference there in Casa Italiana, and so he offered to abdicate on the spot to any other interested individual, institution, or both. And though none took him up on it and his unanointed sovereignty continued, the matter did not rest there altogether. Much later, in 1948, his successor Dr. White expressed much the same misgivings. Then, with the very best interests of the Conference at heart, he actually put the Conference on the block or up for grabs. And the possibility was even suggested of ending the Conference then and there.

But whether out of sentimental attachment for Columbia or sudden panic at the thought of losing out on a long holiday weekend in New York or a combination of the two, the Conference elected to remain where it was. And so far as I know, the twin specters of affiliation and dislocation have not appeared again since.

Properly considered, however, the Conference of Eastern College Librarians has been far more than the sum of its unorthodoxies or of the people who have run it or of the existential perils which have occasionally beset it. As with the tattooed lady who was a poet under the skin, these tend only to be its surface markings. Its true substance, true significance, lie beneath and more particularly, in its subject matter. For perennially that is the Conference's real business-to deliver up the kind of subject matter that will be both stimulating and valuable for those representatives of academic libraries, small and large, who come so faithfully, in such large numbers, and often from so far afield to hear it discussed.

In this connection, a Virginian who has been attending the Conference with some regularity ever since 1939 and who is here again today was asked recently to explain the magnetic attraction that the Conference has held for him and perhaps for others, too. After itemizing some of the magnetic tugs already mentioned, he added one more. This was the prophetic, almost oracular quality of the Conference. "It has," he said, "always been a foreshadowing. Not only has it kept abreast of most of the important things librarians were talking about at any given moment but often a jump ahead of them." And over the years the record would seem to bear the gentleman out.

Certainly one case in point was when Ralph R. Shaw, then librarian of the United States Department of Agriculture, came in 1950 to talk about his Rapid Selector, and that was all of a decade before the Information Retrievalists were in full voice. Surely another was in 1915 when an unidentified speaker called for new union lists of serials-eleven years before the great omnibus wrought by Winifred Gregory. And still another was in 1921 when James T. Gerould of Princeton, twenty-one years before the Farmington Plan, was calling on the research libraries of America to begin differentiating among the fields of their collecting. And the library survey was decidedly an infant art when the subject was first introduced to the Conference by Blanche Pritchard McCrum of Washington and Lee, in 1938.

More examples of the Conference's prophetic gifts might be offered. But let me mention just one more. Whether today's gadgeteers would own her as a spiritual forebearer or not, Ethel M. Fair clearly had the jump on them by at least a half generation when she began collecting exhibits for a Conference talk in 1939 on "New Library Devices and Innovations." Collecting them had not been easy, apparently, and so, near the eve of the Conference, she turned to Dr. Williamson for whatever he might be able to gather up out of Columbia's sup- 
ply. Always helpful, he did what he could, and that resulted in the following items: a pasting machine, an electric typewriter, interchangeable wire partitions, folding open-bar shelves, and electric erasers.

But these were not all. In addition, he offered two items which understandably could not go in a display case but which the Conference was welcome to inspect if it wished. These were Columbia's new electrically-controlled doors to its stacks and its new gravity conveyor belt for the return of books to the college library. And he probably suggested the last item on the well-founded theory that anything that gets books back into the library is information retrieval at its best.

These, then, may be enough to illustrate some of the Conference's futuristic tendencies. But keeping up with the present can be difficult enough and never more so than in the last half century. When the charter group of librarians met here on the Saturday after Thanksgiving in 1912, they did so less than a month after President Wilson's election to his first term of office, only nine months after the sinking of the Titanic, less than three months before the onset of the federal income tax, all of eight years before women won the right to vote, and at a time when some 20 per cent of the children in the United States were their own breadwinners. In 1912 also, world war was still unknown. But since then the relentless present has advanced through two world wars and into a Cold War. It has moved through the eras of the Teapot Dome, the Bonus March, and Blue Eagles, through those of the New Deal, the Fair Deal, and the New Frontier, and on to atoms, astronauts, and antipoverty programs as at present.

But along with these more obvious signs of turbulence, change, growth, and even progress, there have been others to mark the Conference's passage through time, and among them, the simple statis- tics of explosion. In 1912 America's population was around $92,000,000$. Today it nears 200,000,000. In 1912 America had 494 undergraduate and graduate institutions, including ten recognized library schools, and a student enrollment of two hundred and seventy-five thousand. Today it has 1,985 colleges and universities, thirty-four accredited library schools, and a student enrollment nearing four million. Science has its familiar statistic: 95 per cent of all the scientists who ever lived are alive today. And thanks to Abraham Kaplan in the current Library Quarterly, the field of information now has its statistic, too. Namely, that the yearly output of printed words now amounts to approximately ten million words for each man, woman, and child in the United States.

Now the Conference might have ignored these explosions or drawn back from them. Instead, in all the areas appropriate to its mission, it has responded to them not only sensitively but almost seismologically. It has done so in wartime when war has not closed it down as it did three times. In 1917 the Conference discussed the literature of war, what to collect of it, and how. And after reconvening again in 1919 it promptly addressed itself to postwar library problems and needs. Again in the meetings of 1944, 1945, and 1946, it devoted itself either wholly or in part to the subject of desolated libraries abroad and postwar library planning at home. The Conference reacted to Depression too. While apples presumably were being sold on Broadway street corners outside, men like Donald Gilchrist and Henry B. Van Hoesen were considering ways to keep library service afloat in the face of crippled budgets and decimated staffs.

And to the more peaceable explosions of exponential growth the Conference has responded in like manner. From the inaugural meeting in 1912, for example, when Frederick C. Hicks spoke on "Inter-Library Loans," the Conference has 
discussed cooperation in its expanding forms and on its ascending levels no less than twenty-one times. On this theme alone the Conference has passed some monumental milestones, as when Winifred Gregory came to report on her National Union List in 1926; when Ernest Kletsch proposed his idea of a central clearinghouse for interlibrary loans at the Library of Congress in 1935; when Archibald MacLeish, apparently none the worse for his embattled appointment the year before, came in 1940 to seek greater cooperation among American libraries in collecting research materials; or in 1962 when the entire Conference was focused on regional, national, and worldwide levels of library cooperation.

With technology, too, the Conference has kept pace, from the new title-a-line linotype for printing catalog cards in 1915 to the pushbutton instrumentation with its awesome and sometimes alarming capabilities today. When, incidentally, the first sense of human inadequacy in the face of today's mechanized intellection first began to be felt here is not known. Perhaps the maximum impact of it simply awaits the day when not people but computers do the talking here.

The Conference has also studied photographic developments from the day in 1930 when Andrew Keogh brought down Yale's new Dexigraph to prove the camera eye was quicker than the hand in copying catalog cards, down to the present when microfilm teamed with electronics can now store whole libraries in one black box.

This year, the Conference will forecast the future of education for librarianship. But that subject, too, has a long genealogy here, going back all the way to a consideration of the Williamson report in 1923. In fact, the Conference has seldom let much time go by since without trying to settle on the mode of library education which not only will produce day-to-day functional skills but also the larger vision of librarianship that can "trace horizons thin and fine."

With expanding college and university curricula and proliferating honors and independent study programs, the Conference has many times analyzed the library's role in their support. It has also at various times studied library architecture, library administration and recruitment, library budgets, library reserves, and rare books. Indeed there is scarcely any subject of consequence to academic librarianship in the past fifty years or more which the Conference at one time or another has not discussed.

Needless to say, the Conference has not neglected cataloging and classification. These, too, have been persistent themes throughout the years. And the catalog itself in the discussions has progressed through every incarnation from card, to microcard, to book, to electronic catalog at present. In fact, on one notable occasion, catalogers themselves were a topic. This was in 1932 when Roger Howson, then Columbia librarian, may have made his final public bid for their affections when he addressed himself to the question, "Must Catalogers Be Robots?"

In mentioning Mr. Howson's talk, it may as well be noted that the Conference has had its tempestuous moments. Well within recall of many was the day then Jacques Barzun, also of Columbia, spoke on the topic, "The Scholar Looks at the Librarian." It was a rather pained look, evidently. From the temper of the discussion at the time and at least one letter that has survived in the file, I would assume there are still some librarians around who would welcome a return match with Mr. Barzun. And perhaps a few may return to the Conference each year in the frevent hope that one of their colleagues will speak on, "The Librarian Looks at the Scholar."

Now more might be added to this chronicle. As it is, I have all but overlooked the admirable record of the Con- 
ference behind the scenes and the all but anonymous work of people like David Clift, Charles Adams, John Berthel, Lawrence Heyl, Charles Mixer, C. Donald Cook, Kathryn Sewny, Winifred Linderman, and others who have done so much in support of the committees, not only to put on a good conference but to make it a good party as well. A few have asked me as the Conference antiquary if I might not offer some prescription for the Conference's continued longevity and better still, for its eternal youth. But this I must leave to the science of geriatrics in any way it may apply to library conferences.

Entirely as a layman I can only suggest more of the same which has already succeeded. And that is, informality, independence, brevity, timeliness, Manhattan at Thanksgiving time, Morningside Heights, and no more speeches on the history of the Conference than seem absolutely necessary.

\section{For Library Building Planners}

The Library Administration Division of the American Library Association, 50 E. Huron, Chicago, Illinois, can be of great help to library building planners because of the many services it performs.

These services include furnishing a list of library consultants in any area of the country, supplying a list of new college library buildings in each area, providing a list of architects who have designed college libraries in each state, producing bibliographies on college library planning, and sponsoring building institutes preceding the American Library Association annual conference.

One other major service that LAD performs is to provide for loan to librarians throughout the country building program statements, floor plans, photographs and slides of recently constructed junior college, college and university library buildings. LAD's continued high level of service in this area depends to a great extent upon the completeness of its collection of these materials. Due to the marked increase in library building planning and construction at the academic level and the resulting increase in requests for these planning materials, LAD has experienced shortages in various parts of its collection and especially in the junior college section.

Therefore, librarians who have recently been involved in planning a new junior college library building are requested to send any of the above material for their libraries to the Assistant to the Executive Secretary at the above address. Material on recently constructed college and university library buildings would also be most welcome. 